\title{
Identification of Local Seismicity Observed South of Aswan City, Egypt
}

\author{
Sayed A. DAHY*, Gaber H. HASSIB* and Jim MORI \\ *National Research Institute of Astronomy and Geophysics, Helwan, Cairo, Egypt
}

\section{Synopsis}

The Aswan Seismic Net work det ected and observed a number of event s near Aswan city. The magnitude of these events ranged from 0.9 to 2.6. These events were considered very important events because they were located not far from the Aswan High Dam. The main purpose of th is wo rk is to in vestigate and id entify these events using different sei smic methods. Small earthquakes and expl osions have the same flat displacement spectrum for short- period $\mathrm{P}$ wa ves and discrim ination of sm all events depends on detection and location. The final results indicate that the sources of $t$ hese events are natural earthquakes.

Keywords: Aswan High Dam, Seismicity, Explosions

\section{Introduction}

Like earthquakes, the force of an underground explosion creates seismic waves that travel through the Eart h. A sei smic m onitoring net work must be able to detect and identify bot $\mathrm{h}$ types of seismic signals. Det ection consi sts of recogni zing $t$ he seismic event, and locating the source of the seismic signals. Identification involves determining whether the source was an underground explosion or natural earthquake. The identification problem in seismic $\mathrm{m}$ onitoring is called th e $\mathrm{d}$ iscrimination problem. It i s t o di stinguish underground explosions from ot her sei smic sources (Offi ce of Technical Assessment, 1988).

Accurate event location is essential for identification, i ncluding the rel iable separat ion of onshore and of fshore events and the determination of source depth. When location alone is insufficient to identify $\mathrm{t}$ he source, secondary waveform attributes $\mathrm{m}$ ust $\mathrm{b}$ e relied on. Fo $\mathrm{r}$ sm all events, experience has shown $\mathrm{t}$ hat a num ber of methods, often different in different regions, can be used $t o$ distinguish expl osions (e. g., mine blasting) from earthquakes.

Physical differences between earthquakes and explosions cause their seismic signals to differ, and these differences can be used to identify the events. Once a seismic signals has been detected, the next task is to determine whether it was created by an underground explosion.

Seismic signals are generated not only by underground nuclear explosions, but also by natural earthquakes, rockburst $\mathrm{s}$ i $\mathrm{n}$ mines and chemical explosions conducted for $\mathrm{m}$ ining, quarry bl asting and construction. Every day $\mathrm{t}$ here are $\mathrm{m}$ any earthquakes around the globe whose seismic signals are the same size as those of potential underground explosions.

Ericsson(1970) and Basham (1971) indicated that, one of $\mathrm{t}$ he $\mathrm{m}$ ost useful di agnostic ai ds $\mathrm{t} o$ distinguish between eart hquakes and expl osions is using the relative am plitude of surface- wave that are generated for a gi ven short- peri od P-wave signal. Douglas et al. (1972) analyzed seismograms for various sources and showed $t$ hat, for $m$ any orientations of the fault plane, earthquakes generate smaller P-waves $t$ han expl osions for $t$ he sam e 
Rayleigh- wave amplitude. Pulli and Dysart (1987) and $B$ ennett et al (1989) reported $t$ hat the discriminant is less ef fective in sep arating earthquakes and expl osions in Scandi navia and in the eastern European shield, respectively. Again, as pointed out by Bennett et al (1989), propagation path di fferences for the expl osion and earthquake populations may have an effect on the performance of this di scriminant. Dougl as et al (1990), found that the Pn wave i s stronger relative to $\mathrm{Sn}$ and $\mathrm{Lg}$, nad these ratios increase with frequency. This result is due $\mathrm{t}$ o 1 arger hi gh frequency Pn am plitudes relative to the $\mathrm{Lg}$ amplitudes.

\section{Seismological Observations and Data}

On Novem ber 14, 1981, a magnitude 5.3 earthquake occurred in the Kalabsha area along the Kalabsha fau lt near $\mathrm{G}$ ebal Marawa, $70 \mathrm{~K}$ m southwest of the city of Aswan. The earthquake is considered a ver $\mathrm{y}$ im portant even $\mathrm{t}$ because it $\mathrm{i} \mathrm{s}$ located not far fro $m$ the Aswan $\mathrm{H}$ igh Dam. In late June 1982, a telemetered $n$ etwork of eight seismograph stations was installed ar ound the northern $p$ art of Asw an r eservoir by the Nati onal Research Instit ute of A stronomy and Geophy sics, Helwan, Eg ypt and Lam ont- Doher ty Geological Observatory. A ni nth station w as added in December 1982 and the network was expanded to 13 stati ons in 1985 (Kebeasy et al., (19 87). The main purpose of the network is to monitor induced seismic acti vity al ong the Kalabsha fau lt and around High Dam Lake.

The data used in the present investigation were collected fro $\mathrm{m}$ the $\mathrm{r}$ ecords of the A swan Se ismic Network (Fig.1) and also from the records of the Egyptian National Sei smic Network (EN SN). The data set for this study co nsists of 27 unknown events (Table 1) observed close to south of Aswan city and recor ded during the period fro m $1999 \mathrm{t} o$ 2003. Also we u sed abou t 15 quarry explosions near $\mathrm{t}$ he $\mathrm{O}$ ld Aswan $\mathrm{D}$ am and 15 nat ural earthquakes that occurred in different regions along the Seiyal and Khor El Ramla faults, south- west of Aswan zone.

All of these even ts (earthquakes and quarry explosions) $\mathrm{h}$ aving local magnitude $\mathrm{r}$ anging f rom 0.9 to 2.8 and were recorded at the same stati ons with the same type of equipment. The locations are shown in Figure (1).

In th is study, local magnitudes $\left(\mathrm{M}_{\mathrm{L}}\right)$ for these events have been calculated using the magnitudeduration relationship (Lee et al., 1972)

$$
\mathrm{M}_{\mathrm{L}}=2.0 \log \mathrm{D}-0.87
$$

Where $\mathrm{D}$ is the s ignal duration from the $\mathrm{P}$ - wave onset to the end of the discernable signal.

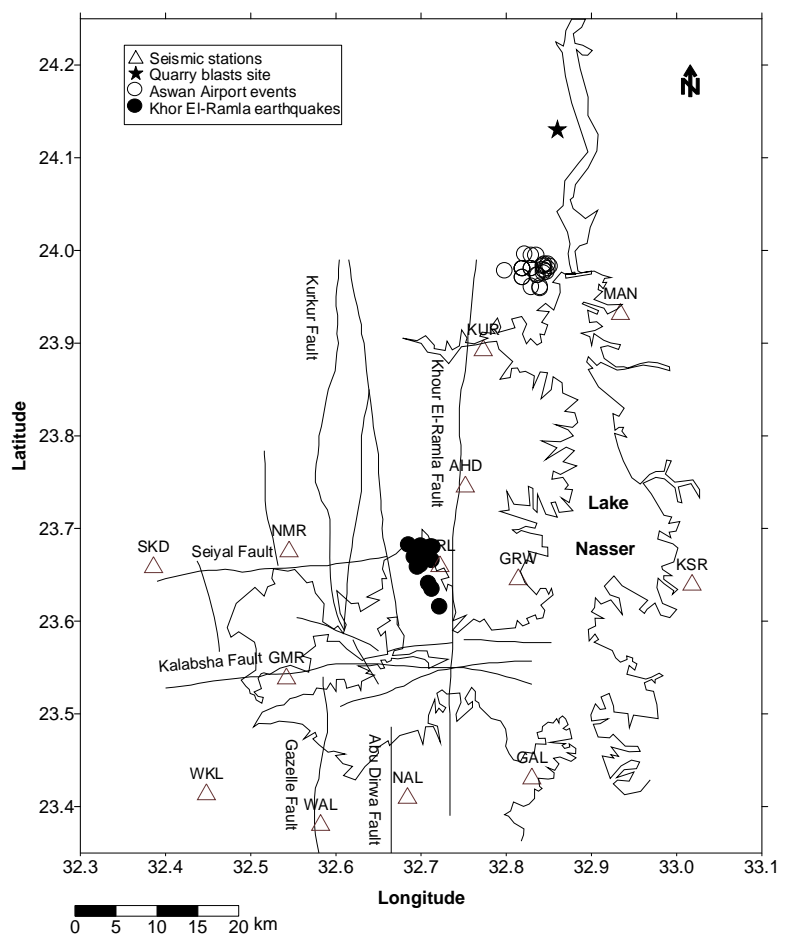

Fig. 1. Geological st ructure and 1 ocation of the investigated seismic events

\section{Local Geological Setting and Active Faults}

The g eology of the Asw an are a is con trolled primarily by regi onal basem ent ro ck upli $\mathrm{ft}$ an $\mathrm{d}$ regional faulting. The River Nile divides the Aswan area into eastern and we stern are as. In the eastern aswan area two broad gro ups of fo lds have been traced. Th e ol der group is found on ly in $t$ he basement ro cks, while the y ounger gro up can be traced in the basement an d overlying sedi ments. The fold axes of the older group trend NE- SW and NNW- SSE. In the western Asw an area th e dominant fold system trends ENE- WSW parallel to 
the younger fold trend in the east ern Aswan ar ea. The ar ea is tr aversed by tw o major fault systems trending and NNW- SSE. Geology of the western

Aswan area i s do minated by a sedimentary successions varying from Cretaceous to Quaternary.

The area west of Aswan is characterized by a great number of faults, and the largest faults are the Kalabsha and S eiyal fa ults (Fig. 1). Seven fa ults were identified as a ctive faults. The nearest faults for this study are,

1) Seiyal fault: The Seiyal fault, about $100 \mathrm{~km}$ long, is located approximately $12 \mathrm{~km}$ to the north of Kalabsha fault at the eastern edge of $t$ he Sinn ElKaddab plateau. It is approximately parallel to the Kalabsha fault. It is also a right- lateral strike- slip fault as indicated b y $\mathrm{r}$ ight- st epping en ech elon folds. From studying the seismicity, it is less active than the Kalabsha fault.

2) Kurkur fault: This fault is a N-S trending fault, about $44 \mathrm{~km}$ long. It runs about $28 \mathrm{~km}$ to the west of the High Dam. It is interpreted to be a leftlateral strike- slip fault indicated by the small leftstepping en echel on folds co mmon al ong the fau lt trace (Issawi, 1968; 1978). Sei smic activity of the Kurkur fault is estimated to be very low.

3) Kh or El R amla fault: This fault is a N - S trending fault with total length of about $36 \mathrm{~km}$, and it is approx imately $17 \mathrm{k} \mathrm{m}$ sout hwest of the $\mathrm{H}$ igh Dam at its c losest approach. A c luster of microearthquakes $t$ hat $t$ rends approxi mately $\mathrm{N}-\mathrm{S}$ has been $r$ ecorded around the southern end of the fault. Th e fa ult $p$ lane so lution of these ev ents indicates left lateral faulting. The degree of activity of the Khor El Ramla fault was estimated to be very low.

\section{Seismicity of the Aswan Region}

The sei smicity of Asw an regi on $\mathrm{h}$ as been studied by many seismologists (e. g., Simpson et al., 1985, Kebeasy et al ., 198 7, El - Khash ab et al., 1991). Si mpson et al ., (19 86) i ndicated that the seismicity of the Aswan area is concentrated in two distinct clusters on and near the Kalabsha fault. The 1981 event and its aftershocks are at depths of 12 to $25 \mathrm{~km}$. East of the Kalabsha $\mathrm{f}$ ault, there are two shorter segments of activity at depths of 0 to $10 \mathrm{~km}$.
The highest level of activity is at depths of 15 to 30 $\mathrm{km}$ beneath Gebel $\mathrm{M}$ arawa. $\mathrm{T}$ he s eismicity elsewhere is less than $15 \mathrm{~km}$ deep.

Woodward- Cly de Consultants, (1985) concluded from st udying the historical and recent seismic activity that the area is ch aracterized by a low level of seismic activity. The majority of local earthquakes recorded by a temporary network from 13 Decem ber $1981 \mathrm{t}$ o 6 July 1982 were concentrated along the Kalabsha fault. The map in figure (2) shows the seismicity for the period from 1982 to the end of 2003. Most of the seismicity is concentrated at Gebel Marawa al ong the Kalabsh a fault and its extension towards east. Other activity is located in the Khor E 1 Ramla area w est of the Khor E 1 Raml a fa ult. Some of these e vents are located along the Abu D irewa $f$ ault a $t$ a focus depths of 0 to $6 \mathrm{~km}$. Few events are observed in the northern part of High Dam Lake close to the Aswan International Airport.

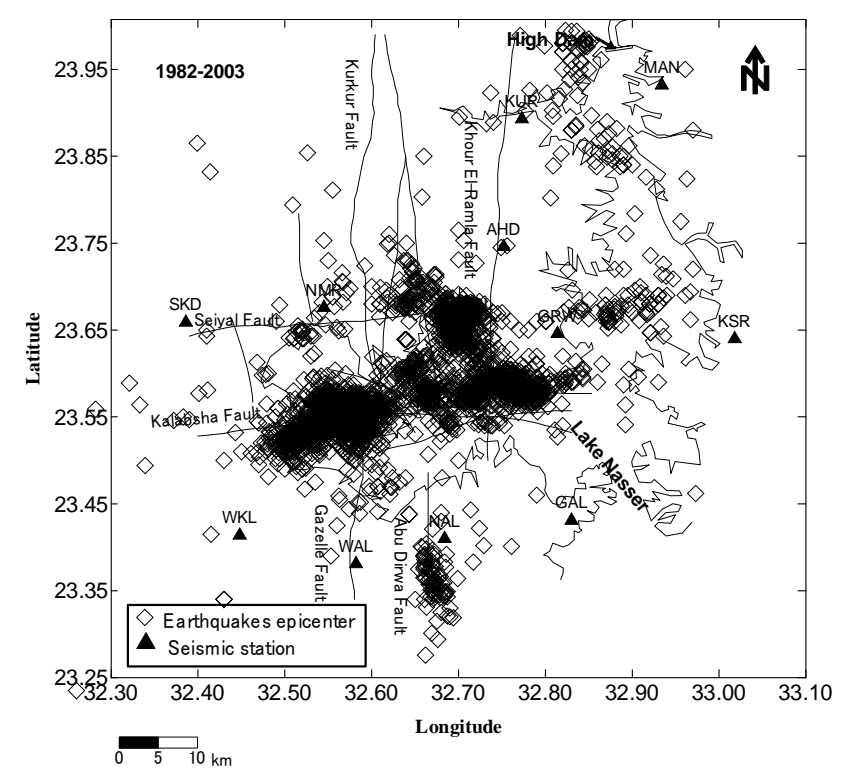

Fig. 2: Seism icity map of Kal absha area fro $\mathrm{m}$ January 1982 to Dece mber 2003. The lake ou tline refers to the water level of $180 \mathrm{~m}$.

In Fig. 3, the number of earthquakes are shown for 22 years for the time period from January 1982 to December 2003. The mai $\mathrm{n} l$ evel of seism icity decreases $w$ ith sever al pe aks in the shallow and deep seismic activity that occurred within a few 


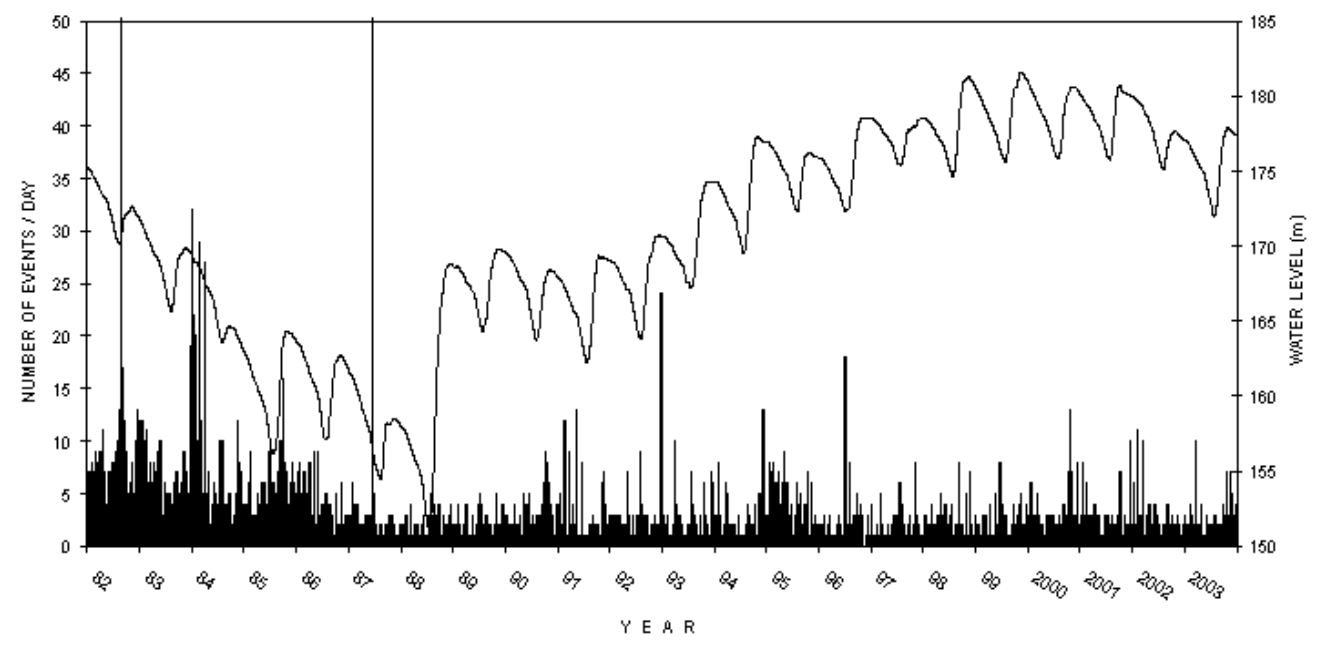

Fig. 3. Examples of quarry explosion and two natural earthquakes

Table 1: List of unknown events observed near Aswan Airport

\begin{tabular}{|c|c|c|c|c|c|c|c|c|c|}
\hline & Mon & Day & hr & min & sec & Lat. N & Lon. E & Depth & Mag. \\
\hline 1999 & 11 & 6 & 11 & 10 & 46.2 & 23.98 & 32.82 & 3.3 & 1.7 \\
\hline 1999 & 12 & 4 & 13 & 40 & 0.3 & 23.98 & 32.82 & 4.3 & 1.7 \\
\hline 1999 & 12 & 5 & 6 & 35 & 23.7 & 23.98 & 32.82 & 3.5 & 1.1 \\
\hline 1999 & 12 & 22 & 7 & 39 & 21.39 & 23.975 & 32.844 & 0.71 & 2.6 \\
\hline 1999 & 12 & 22 & 14 & 24 & 52.5 & 23.97 & 32.82 & 5.7 & 1.1 \\
\hline 2000 & 1 & 8 & 0 & 31 & 43.9 & 23.96 & 32.83 & 2.6 & 1.6 \\
\hline 2000 & 1 & 8 & 20 & 17 & 35.35 & 23.98 & 32.83 & 1.13 & 0.9 \\
\hline 2000 & 1 & 9 & 3 & 39 & 18.91 & 23.97 & 32.82 & 1.76 & 1.4 \\
\hline 2000 & 1 & 13 & 5 & 37 & 0.35 & 23.98 & 32.83 & 1.6 & 1.4 \\
\hline 2000 & 1 & 13 & 6 & 16 & 22.82 & 23.98 & 32.82 & 1.13 & 1.1 \\
\hline 2000 & 3 & 17 & 19 & 58 & 44.9 & 23.995 & 32.823 & 1.39 & 1.8 \\
\hline 2000 & 8 & 31 & 2 & 12 & 27.66 & 23.96 & 32.84 & 0.13 & 2.2 \\
\hline 2002 & 1 & 13 & 3 & 49 & 19.4 & 23.994 & 32.83 & 24 & 1.9 \\
\hline 2002 & 5 & 11 & 8 & 52 & 27.2 & 23.985 & 32.85 & 2.93 & 2.0 \\
\hline 2002 & 9 & 3 & 0 & 2 & 24 & 23.984 & 32.846 & 1.23 & 2.3 \\
\hline 2002 & 9 & 3 & 0 & 9 & 28.4 & 23.982 & 32.852 & 4.87 & 1.8 \\
\hline 2002 & 9 & 3 & 6 & 48 & 40.5 & 23.972 & 32.838 & 0.98 & 1.7 \\
\hline 2002 & 9 & 3 & 8 & 3 & 40.4 & 23.976 & 32.848 & 2.37 & 1.2 \\
\hline 2002 & 9 & 4 & 5 & 7 & 54.1 & 23.977 & 32.846 & 0.47 & 1.4 \\
\hline 2002 & 9 & 7 & 7 & 48 & 57.7 & 23.98 & 32.85 & 0.97 & 1.9 \\
\hline 2002 & 9 & 9 & 17 & 57 & 48.7 & 23.983 & 32.844 & 1.16 & 1.6 \\
\hline 2002 & 9 & 12 & 4 & 24 & 18.6 & 23.978 & 32.844 & 0.92 & 1.1 \\
\hline 2002 & 10 & 13 & 15 & 23 & 8.6 & 23.958 & 32.841 & 0.27 & 1.7 \\
\hline 2003 & 5 & 26 & 0 & 21 & 44.6 & 23.982 & 32.845 & 0.14 & 2.2 \\
\hline 2003 & 6 & 6 & 7 & 44 & 41.6 & 23.994 & 32.836 & 0.04 & 1.8 \\
\hline 2003 & 6 & 19 & 19 & 45 & 2.81 & 23.977 & 32.799 & 3.69 & 0.9 \\
\hline 2003 & 7 & 12 & 6 & 13 & 22.75 & 23.973 & 32.837 & 0.49 & 1.3 \\
\hline
\end{tabular}


weeks after the annual seasonal water level maxima. Few even ts dete cted and observed near Aswan Airport a re associated with the increasing the lake water level to 180 meter.

\section{Event Identification}

The a im o $\mathrm{fth}$ is s tudy is to ev aluate th $\mathrm{e}$ effectiveness o f some di scriminants by investigating am plitude spect ra an $d d y$ namic characteristics of the waves generated by different types of sour ces in a certain region of Aswan. Th e source properties of quarry explosions, the dynamic characteristics of $\mathrm{t}$ heir $\mathrm{w}$ aves ( amplitude, peri ods and wav eform) and comparison w ith the characteristics of $n$ atural ear thquakes have $b$ een mainly studied for quarry explosions.

Each seism ic source can be described by its space-time par ameters ( volume, location, d epth of the source, origin time) and its dynamic parameters (energy, magnitude, spect rum). For seismi c even ts that cannot be disti nguished by depth and location, other methods of discrimination are used and these methods are based on physical differences between earthquakes and exp losions. So me of the applied methods af ter $\mathrm{m}$ odification can be used for identification of local seismicity that occurred near Aswan International Airport.

Waveform Characteristics One of the most important probl ems in sei smic monitoring i s to distinguish under ground expl osion from other seismic sources. If a seism ic event is sm all the problem of di scrimination i s not st raightforward. Explosions release their ener gy in a very sm all volume and produce primarily $\mathrm{P}$ waves. In contrast, earthquakes represent the motion of blocks along a fault; the so urce dimensions are $\mathrm{m}$ uch larger for a given si ze than for an explosion, and earthquakes produce large $\mathrm{S}$ waves.

Below is a figure (4) com paring two recent natural eart hquakes with a quarry expl osion of approximately the sam e size. Both events were recorded $b$ y th e Egyptian Natio nal Seismic Network with the same type of equi pment and the distance between $\mathrm{t}$ he expl osion and recordi ng station is approxim ately the sam e as the distance between the earthquake and recording station. The explosion waveform is dom inated by the $\mathrm{P}$ wave (first arrival), while the earthquake has much large $\mathrm{S}$ waves (and surface waves).

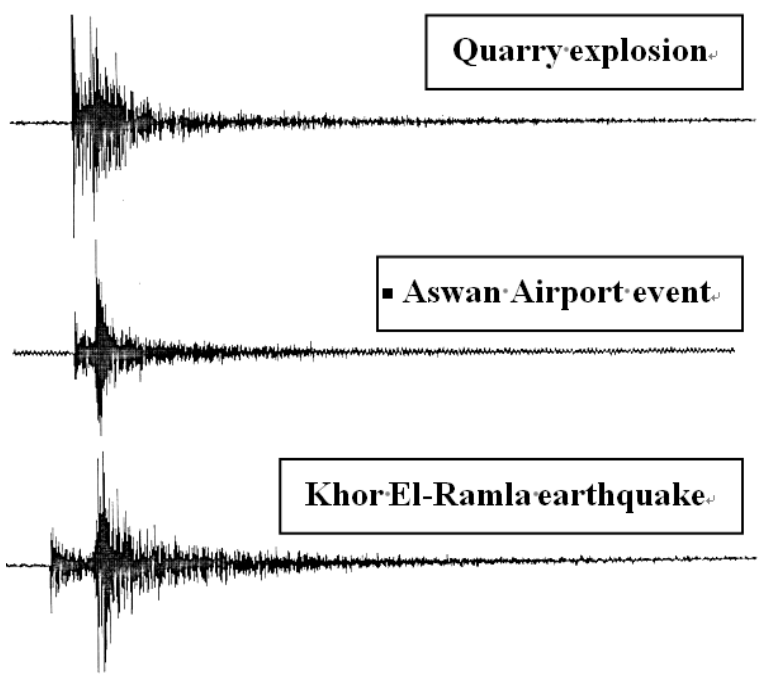

Fig. 4. Exam ples of quarry expl osion and two natural earthquakes.

On the ot her hand, the durat ion of expl osion source processes is shorter and the oscillations have an im pulse character. This characteristic and the increasing hi gh frequency com ponent absorption cause the more rapid at tenuation of the explosiongenerated oscillations with distance. The explosions are spherically symmetric centers of energy, so the explosion generat ed $\mathrm{P}$ - wave are recorded at all seismic stations as waves of compression. For the natural eart hquakes $\mathrm{i} n \mathrm{t}$ he regi on under investigation, the first $\mathrm{m}$ otion can $\mathrm{b}$ e eith er $\mathrm{a}$ compression phase or dilatation phase, which is due to the specific mechanism of the earthquake source. Body to Surface Wave Amplitudes The ra tio between body- wave $\mathrm{t}$ o su rface- $\mathrm{w}$ ave am plitude (Ap: As) i s used when i nvestigating t he natural earthquakes and presumed quarry explosions.

Underground exp losions li ke industrial explosions in quarries generate signals, which tend to have surface or S- wave amplitude (As) and body wave amplitude (Ap) $t$ hat di ffer fro $m t$ hose of natural earthquake signals. This is basically a result of explosions emitting more en ergy in the form of body w aves (high- frequency sei smic $r$ adiation), and earthquakes emitting more energy in the form of surface waves (low- frequency seismic radiation). To use this identification method, both Ap and As 


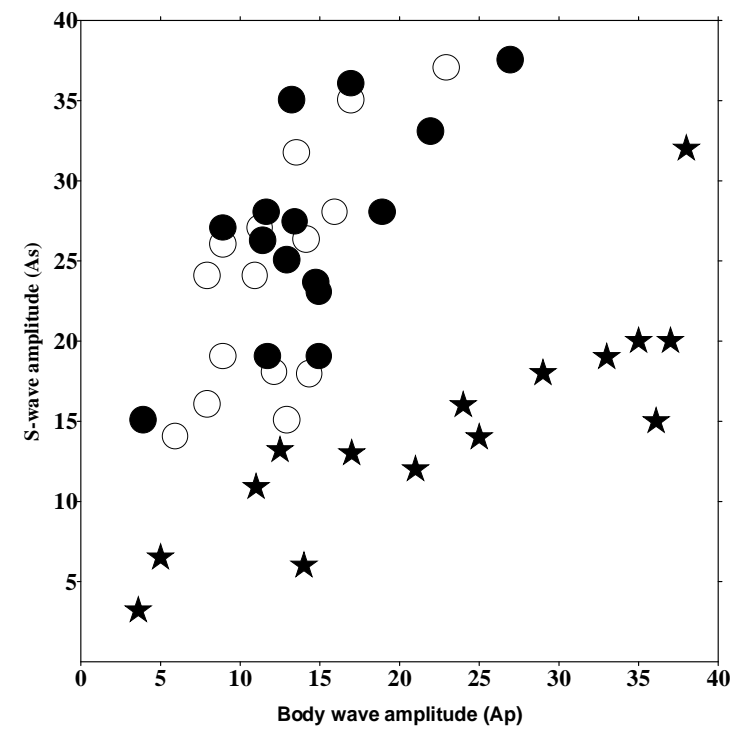

Fig. 5. Relation between body wave and S-wave amplitude (Ap: As). Khor El Ramla earthquakes (close circle), Airport events (open circle) and quarry explosions (star).

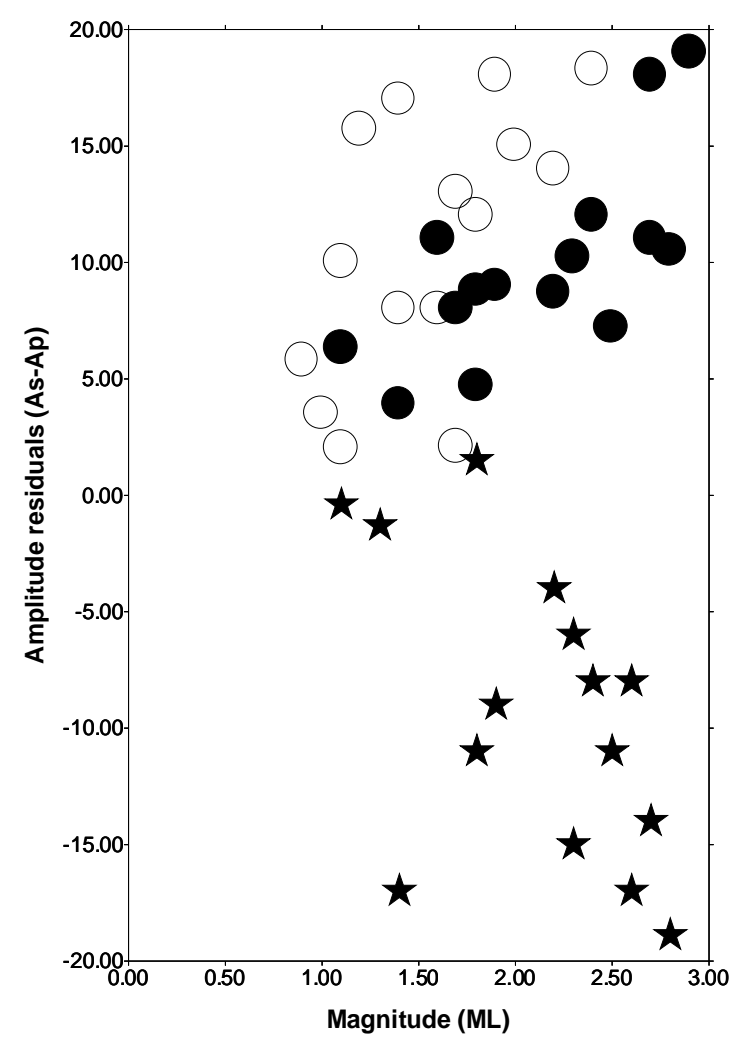

Fig. 6. Relation between local magnitude $\left(\mathrm{M}_{\mathrm{L}}\right)$ and amplitude residual (As-Ap) values ( maximum trace am plitude of $\mathrm{P}$ and $\mathrm{S}$ waves in $\mathrm{mm}$ ) a re req uired. The re lationship between $t$ he $m$ aximum $t$ race am plitude on $t$ he seismogram of P-w ave (Ap) and S- wave (As) for events which occurr ed in or nea $r$ the Asw an International Airport and Khor El R amla earthquakes w ith qu arry ex plosions fired near the Old Aswan Dam are shown in Fig. 5.

It can be seen that quarry explosions are clearly distinguished from the A irport events and Khor El Ramla ea rthquakes, espe cially in th e lar ge amplitude range and $t$ he separation can be $m$ ainly attributed to the difference in the source nature.

Generally it is observed $t$ hat, P- wave amplitude for explosions are greater than those of earthquakes. Also S- wave amplitude for explosions are 1 ess $t$ han $t$ hose of ear thquakes. Th is can be explained that, in case of expl osions most of the released en ergy is confined in the $r$ ange of high frequency waves. On the contrary, for earthquakes the released energy is distributed in a large range of frequencies. In addition, quarry explosions do not, generally generate large S- waves as they are fired near the earth's surface.

Amplitude Residuals of Local Magnitude. The relation bet ween $\mathrm{M}_{\mathrm{L}}$ and deviations of maximum trace a mplitude on th e $\mathrm{s}$ eismogram namely is shown $\mathrm{i}$ n Fig. 6. For $\mathrm{q}$ uarry exp losions, the deviations are $\mathrm{m}$ ostly minus when $\mathrm{t}$ he $\mathrm{m}$ aximum trace amplitude of $\mathrm{P}$ - wa ve is gr eater than th $\mathrm{e}$ maximum trace amplitude of S- wave. Earthquakes in bo th r egions show $\mathrm{v}$ alues for am plitudes of $\mathrm{S}$ wave are greater than those of P- waves.

These si gnificant dev iations ar e prob ably due to the response of the short-period seismograph and the spectra of underground explosions, which have a strong peak at a higher frequency and a relatively simple pattern, as is easily seen from the analogue records. It is also significant th at, the sp ectra of quarry explosions near the old Asw an Dam appear very similar. On the other hand, for earthquakes, the spectra are mor e co mplicated and app ear very different from those of explosions.

\section{Conclusions}

These investigations are related to the problem of identification of qu arry exp losions and sm all 
earthquakes. The results of the present study show that: wa veform characteristics of seismic wa ves generated b y 1 ocal earthquakes and quarr $\mathrm{y}$ explosions can be used as a diagnostic ai $\mathrm{d}$ in distinguishing between the two types of events.

Separation $b$ etween nat ural ear thquakes and underground quarry explosions is observed clearly in the $\mathrm{r}$ elation bet ween $\mathrm{P}$ wave and $\mathrm{S}$ wave amplitudes (Ap: As), as calculated from the records of the Aswan short- period seismic stations.

Using the relation between local magnitude and amplitude residuals (As- Ap) for dif ferent local events which occur in different regions with known quarry exp losions, it was possi ble to distinguish underground quarr $\mathrm{y}$ explosions fro $\mathrm{m}$ natural earthquakes. The capability of this $d$ escribed method $\mathrm{t}$ o di fferentiate bet ween natural and artificial events is tested and shows good results.

By app lying these methods to Aswan A irport events, we conclude that, th ese ev ents are no $t$ artificial ev ents bu $t$ all even ts are natur al earthquakes. The most gen erally ac cepted explanation $f$ or $t$ he cause of the ear thquake occurrence in su ch cases is that ro cks near the Aswan reservoir are already strained from the local and regional tectonic forces to a point where nearby faults are a lmost ready to s lip. Water in the $\mathrm{High}$ Dam Lake adds a pressure perturbation that triggers the fau lt rup ture. The pr essure effect, $p$ erhaps, is enhanced by the fact that the rocks along the fault have lower strength due to i ncreased wat er- pore pressure.

\section{References}

Basham, P. W. and Whitham, K. (1971):

Seismological det ection of under ground nuclear explosions, publ ications of the Eart h Physics Branch, Department of Energy, $M$ ines and Resources, Ottawa, Vol. 41, pp. 145-182.

Bennett, T. J., Barker, B.W., Mclaughlin, K.L. and Murphy, J.R. (1989): R egional di scrimination of Quarry bl asts, eart hquakes and underground nuclear explosions, Fi nal Report, GL-TR - 890114, S- Cubed, La Jolla, California.

Douglas, A., Hudson, J.A., and Blamey, C. (1972): Quantitative ev aluation o f seism ic sig nals at teleseismic distances. III. Computed P and
Rayleigh wave sei smograms, Geophy s. J. Int ., Vol. 28, pp 385-410.

Douglas, A., Richardson, L. and Hut chins, M. (1990): Surface reflections and $\mathrm{S}$ to $\mathrm{P}$ conversions on P sei smograms, Geophy s. J. Int. Vol. 100, pp. 303- 314.

El-Khashab, H. M. A., Hassib, G.H., Ibrahim, E.M. and Dessoky , M .M. (1991): Sei smicity and composite focal $\mathrm{m}$ echanism for microearthquakes in Kal absha area west of Aswan Lake and their tectonic implication, J. of Geodynamics, Vol. 14, pp. 87-104.

Ericsson, U. A. (1970): Event identification for test ban control. Bu 1l., Seismol. So c. Am. Vol. 6 0, No. 5, pp. 1521 - 1546.

Issawi, B. (1968): The g eology of Kurkur Dungul area, G eneral Eg yptian Or ganization for Geological R esearch an d Mining; Egyp. Geological Survey paper No. 46, Cairo, 102 p.

Issawi B., (1 978): G eology of Nub ia West ar ea, Western Desert, Egypt, Ann. Geol. Survey Egypt, Vol. 3, pp. 237- 253

Kebeasy, R. M., Simpson, D. W . and Gharib, A., (1987): Induced sei smicity around Aswan Lake, 29th G eneral Assem bly of IUGG (I ASPEI), August 1987, Vancouver.

Lee, W. H. K., Bennett, R. E. E. and Meagher, K. L (1972): A m ethod of est imating $m$ agnitude of Local Earthquakes from si gnal durat ion, U. S. Geological Survey Open- File Report, 28 p.

Office of Techni cal Assessm ent, (1988). Seismic verification of nucl ear tests $t$ reaties. U. S. Congress, Office of Technology Assessment.

Pulli, J. J. and Dysart, P.S, (1987): Spectral study of regional eart hquakes and chem ical expl osions recorded at the NORESS array, Technical Report, C 87-03, cent er for sei smic st udies, Arlington, Virginia.

Simpson, D., Kebeasy, R., Maamoun, M., Ibrahim, E., and Megahed, A., (1985): Induced sei smicity around Aswan Lake, T ectonophysics, Vol. 118, pp. 281 .

Woodward- Clyde Consultants, (1985). Earthquake activity an d stability ev aluation for the Aswan High Dam, R eport, Hi gh and Aswan Dam Authority, Ministry of Irrigation, Egypt. 


\title{
エジプトアスワン市南部で観測された地震活動の検出
}

\author{
Sayed A. DAHY* • Gaber H. HASSIB* • Jim MORI \\ * National Research Institute of Astronomy and Geophysics, Helwan, Cairo, Egypt
}

要 旨

アスワン地震観測網により, アスワン市周辺で多くの地震が観測された。これらの地震のマグニチュードは0.9から 2.6 であった。アスワンハイダムからそれほど遠くないところを震源とすることから重要なイベントである。この研究の 目的は，異なる地震学的手法を用いてこれらの地震を調べることである。小地震と発破は短周期のP波では同じ平坦な变 位スペクトルをもち，震源位置によって小地震を識別する必要がある。これらの地震は，自然地震であると結論づける ことができる。

キーワード：アスワン・ハイ・ダム，地震活動，爆破 